\title{
Corporate Social Responsibility Practice of Multinational Companies in Ethiopia: A Case Study of Heineken Brewery S.C
}

\author{
Berihu Gereziher $^{1 *}$ and Yohannes Shiferaw ${ }^{2}$ \\ ${ }^{1 \& 2}$ School of Journalism and Communication, College of Social Sciences and Humanities, Addis Ababa University, Ethiopia. \\ *Correspondence: bgereziher12@gmail.com
}

\begin{abstract}
Multinational profit-making organizations are expected to carry out their Corporate Social Responsibilities (CSR) in order to protect the environment and the safety of people living in the surrounding of their plants. The main aim of this study was to explore the CSR practices of a multinational brewery company in Ethiopia, Heineken brewery, with specific reference to the brewery plant in Kilinto. The researcher explored the CSR practices with respect to Elkington's CSR triple bottom line and a specific focus on the people and planet perspectives. Relevant literature was reviewed to describe multinational companies CSR practices in developed and developing countries perspectives. The qualitative research method was used in the study with a case study approach since this research is about a specific case in a specific company. Semi-structured interviews, observation and document analysis were used to collect data. The qualitative content analysis method was used to analyze the qualitative data and describe the meaning. The researcher examined the data in a systematic way in relation to the research questions reducing the data by coding and categorizing to draw meaning. The findings indicate that Heineken lacked balanced CSR practice in its environmental and social CSR practices. Though the company took part in some philanthropic CSR activities, its CSR approach was short term and reactive instead of being proactive. Heineken's CSR strategy needs modification to customize its global CSR strategies into local contexts to solve local problems. Based on the findings, the researcher recommended that Heineken needs to make improvement in its CSR to sustainably address environmental and social needs with stronger community engagement and communicating its CSR efforts through effective PR practice.
\end{abstract}

Keywords: Corporate Social Responsibility, MDGs, Multinational companies, Practice and Public relations.

\section{INTRODUCTION}

There is no agreed definition of Corporate Social Responsibility (CSR); different international organizations and renowned scholars defined CSR differently. For the sake understanding the term CSR, the researcher looks at some of them. CSR can be defined as "responsibilities to society beyond that of making profits for the shareholders." Han et al. (2009) CSR is beyond a donor receiver relationship between the society and the company neither is it a mere UniversePG I www.universepg.com compliance to the legal requirements of the host country. According to Sharma \& Mehta (2012), "CSR refers to the firm's consideration of and response to issues beyond the narrow economic, technical and legal requirements of the firm". These responsibilities were later divided into four parts of responsibilities that multinational companies should shoulder. These are: economic, legal, ethical and philanthropic responsibilities. Besides, Carroll added that CSR crossed borders and cultures as never before. Due to the positive impact of CSR on corporate bottom line, 
CSR is becoming increasingly a buzz word in today's business world. For companies to stay in operation, they should care not only about their shareholders' interests but also should place more emphasis on areas like CSR apart from solely profit making. Most people used to think that businesses are taking advantages from consumers in developing countries. However, nowadays, stake holders are not only concerned about profits; they are more interested in company's engagement regarding various economic, environmental, ethical, governance, and social aspects. The aforementioned issues significantly affect the fate of the company in the long term. There is a competitive advantage for companies with high reputation and these companies are more socially responsible in their CSR programs (Chan, 2014).

As part of their responsible and ethical business, multinational companies have a well-established CSR program. Heineken brewery also claims it has its own CSR program. This thesis, therefore, investigates the CSR practices of a multinational beverage company in Ethiopia, Heineken brewery, and its CSR practice in a country different from the home country of the company in terms of culture, tradition and economic status. Since recently, Ethiopia has begun touting about its conducive investment opportunity mentioning the cheap labor and electricity as its selling points. The first impression many people have towards multinational companies is that they are taking advantage of the community and environment they are operating in. They tend to think that companies are more interested in making profit and care less about other environmental, ethical and human right issues. A number of Ethiopians working in MNCs in Ethiopia were heard complaining about lower wages and ill treatment by MNC employers. Despite this, businesses are now trying to balance CSR and profitability. In this study, the researcher finds out what Heineken is doing as part of its responsible business besides profit making. "Transnational corporations (TNCs) are incurporated or unincorporated enterprises comprising parent enterprises and their foreign affiliates. A parent enterprise is defined as an enterprise that controls assets of other entities in countries other than its home country, usually by owning a certain equity capital stake."
The multinational company in point, Heineken brewery, is based in the Netherlands and operates in 192 countries in the world. This company, like many others, is expected to take part in CSR activities towards the society and environment within which it operates and on which its existence depends. Heineken like any other multinational companies also has duties such as protecting and promoting human rights as part of its CSR activity. The question is what did Heineken do as part of its CSR? These points are discussed in this thesis. Heineken is operating in a country where the stakeholders and the publics' needs are completely different from its home country. This substantiates the need for CSR for sustainable business. Being a socially responsible enterprise was the surest path to legitimacy in these countries." MNCs need for legitimately operating in the host country is one reason pushing them toward practicing CSR.

\section{Statement of the Problem}

Ethiopia has been actively engaged in attracting investment and companies from across the world have started to take part in various investments to make use of opportunities Ethiopia is providing. As one of the fast developing countries in the continent (according to the government of Ethiopia), giant multinational companies are expanding their businesses to Ethiopia as their gate way to Africa. The researcher wondered whether there is CSR involvement of these Multinational companies or they are just taking advantage of the tax holiday and cheap labor and electricity. Despite their number, people informally complain against the multinational companies responsible business practices. There is lack of research in CSR in Ethiopia as it is a recent phenomenon as compared to the developed countries where CSR is believed to be originated. There are, however some studies conducted in local companies. The aforementioned researches in Ethiopian companies are similar in that CSR is explored from Ethiopian perspective with almost similar stakeholders whose culture and demand is easily understood by the companies. These companies operate in the environment they are familiar with. Hence, in this study, MNCs CSR practice will be explored. The researcher examined the CSR practices of Heinekens with focus on the people and planet bottom line of the 
3Ps (profit, people and planet) in CSR. There are unconfirmed theories that MNC are taking advantage of the population and land resource of the developing countries by pretending to take part in CSR while simply green-washing. Even though there is an increasing demand for ethical and responsible business in developing countries, research conducted in CSR of MNC maintaining the cross cultural ethical values are scanty. Leading MNCs consistently are positive forces for both economic development and environmental health and safety quality in the developing countries in which they operate. Heineken is a MNC established for profit and the brewery company uses resources from the community which in turn demands it to be socially responsible and rehabilitate the environment so that the business can sustain. In this study, the researcher explored what a MNC, Heineken Brewery, is carrying out as its CSR in Ethiopia with the triple bottom line in focus in particular reference to the people and planet.

\section{Objectives of the Study:}

The main objective of this study is to explore the CSR practices of multinational companies in Ethiopia with specific reference to Heineken Brewery factory. The specific objectives are therefore to -

- Explore how Heineken practices its CSR to conserve the environment;

- Identify the activities Heineken does to promote and protect the wellbeing of the society;

- Compare the company's CSR performance to Elkington's people and planet bottom line.

\section{Research Questions:}

The study aims to answer the following research questions:

- How does Heineken work to conserve and improve the quality of the environment?

- Does the company take part in CSR activities aimed at protecting the wellbeing of the society?

- What is Heineken's CSR like as compared with Elkington people and planet bottom line?

\section{Significance of the Study:}

As mentioned before in the introduction part of this study, there are little or no study conducted in CSR of
MNCs in Ethiopia. Hence, this may help upcoming researchers as a starting point for further studies. This study might also help MNCs who intend to invest in Ethiopia to get a brief understanding of some CSR activities worth taking part in when they operate in Ethiopia. Besides, it is hoped that the study contributes to the CSR policy making for the government of Ethiopia.

\section{Scope of the Study}

The thesis solely focuses on the CSR practices of a MNC, Heineken, in Ethiopia. This is only to look in to their CSR practice in a developing country from the triple bottom line context. The time is delimited to the whole operating years since the opening of its own brewery plant in Addis Ababa, Ethiopia. The thesis is limited to the people and environment in the vicinity of Heineken brewery plant around Kilinto. The brewery plant is located in Addis Ababa city administration Kalitysub city Wereda 9. The researcher only explores the people and planet aspect of the triple bottom line (doesn't include the profit).The study doesn't include wastage management in to its scope as it requires deep expertise knowledge of the matter.

\section{Limitation of the Study}

CSR can be all encompassing and sometimes difficult to understand in the given limited resource the researcher has. Time is a crucial resource in collecting the required data and analyzing it using supporting evidence. Money is another hindrance in a developing country like Ethiopia as enough budget is not allotted to conduct researches. Subjectivity is one of the common limitations in qualitative research. However, the researcher reduced it using varied data sources and triangulation of data collection methods. The study is limited to only one company. A more elaborate and robust result would have been obtained if more companies had been included. Limited data was used due to the aforementioned constraints and the researcher feels that more result could have been obtained if more subjects were involved in the study. Despite the attempts made to interview the corporate relations manager of Heineken Ethiopia, the researcher couldn't get hold of her. The researcher feels that the study falls short of the desired information from the management of the company and management's 
understanding of CSR is not included in the study. Even though the information accessed from the company's web site was sufficient enough for in-depth analysis of the study, the inclusion of Heineken's management point of view could have contributed to beef up the study.

\section{LITERATURE REVIEW}

CSR history dates back to 5000 years in Ancient Mesopotamia around 1700 BC. King Hammurabi introduced a code in which builders or farmers were put to death if their negligence caused the death of others or major inconvenience to local citizens. By the 1920s discussions about the social responsibilities of business had evolved into what we can recognize as the beginnings of the "modern" CSR movement. "The phrase CSR was coined in 1953 with the publication of Bowen's Social Responsibility of Businessmen.” Even though CSR is a very common term in a contemporary society these days, there is no agreed definition of it as it is a very broad concept consisting of multifaceted issues. Scholars define CSR in different ways and the practices vary from one company to another. The International Labor organization described the following definition by the European commission as the most widely accepted definition in the first decade of the $21^{\text {st }}$ century. i.e. A management concept whereby companies integrate social and environmental concerns in their business operations and interactions with their stakeholders on a voluntary basis.

The commission further emphasized that CSR is beyond compliance to government legal requirements and it includes investing more in human capital and the environment. It reads;" This is an indication that social responsibility is not solely left for the big multinational companies, as thought by many, but it should be practiced by everyone as part of a society. Corporate engagement with society, also termed CSR, has become a commonly used term in contemporary society and refers to one process by which an organization expresses and develops its 'corporate culture' and social consciousness (Rupp et al., 2006; Denzin \& Lincoln, 2011). It has become customary for a great deal of companies to see their CSR initiatives and spread the news that they are carrying out their responsibility to the society thereby conveying the message that they are eligible and have the license to operate. Now a days, there is an increasing pressures from society regarding social and environmental issues and corporations consider CSR in response to the pressure (Miller and Guthrie 2007).

CSR is a self-regulating business model that helps a company be socially accountable to itself, its stakeholders, and the Public. What's more, CSR is beyond taking part in charitable activities or philanthropy. It is about sustainability and inclusive growth. It is a responsibility to develop the society by envisioning the future social, economic and environmental justice and welfare of the community. Therefore, companies have integrated CSR in their businesses and corporate executives encountered demands from multiple stake holder groups to allocate resources to CSR ( $\mathrm{Zu}$ and Song, 2008). Therefore, for a company to sacrifice its profits, it has to go beyond its legal and contractual agreements or mere compliance to the law of the country. CSR embraces a wide range of behaviors, such as being employee and environment friendly, ethical, respectful for the community where it operates and also has to be investor friendly. Hence, MNCs need to assess their impact on the environment and social wellbeing of the community as they have to be accountable for their actions. Sometimes, the call for duty can be extended to go beyond the corporation's immediate realm to include supporting the arts or other good causes. According to Hopkins (2004) CSR can be defined as treating the stakeholders of the firm ethically or in a responsible manner. Ethics is only one aspect of business but by responsible, it includes other responsibilities like legal, economic and social or environmental ones.

\section{Corporate social responsibility and public relations}

CSR is company's responsible and transparent practice complying the government laws and being ethical and concerned about the betterment of the society. The role of PR here is to effectively communicate the CSR and keep people informed about the organization's CSR initiatives so that the CSR of the company be misunderstood as a marketing strategy, rather as a genuine commitment to respond to concerns and make a positive difference in society. The PR can, however, 
develop a campaign strategy to let the public know about the identity of the company and what they stand for. By doing so, CSR and PR can work together for the benefit of the company (Wilcox and Glen, 2006). Slogan positioning PR practice is often employed by companies to say that their products and service are unique. They use slogan positioning to communicate their CSR to their stakeholders to differentiate their activities from those carried out by other competitors. According a research conducted in Indonesia about $50 \%$ of government enterprises practiced one way communication of CSR i.e. only disseminating the information about their CSR activities. The two symmetrical PR has a balanced effect with of the public and stakeholders to solve environmental and social issues (Koswara, 2005). The issue of credibility to CSR communication can be improved by adding third party communication (Dawkins 2004). Even though the relationship between corporate PR and CSR is not well developed, Clark (2000) describes the relationship in that both Public Relations and CSR work to improve the relationship between the society and stakeholders. Public relations professional explore the political social and economic environment to help the organization develop CSR program She added that CSR activities and PR tactics strengthen the relationship between the organization and its publics (Clark, 2000). There is an inevitable link between CSR and PR in similar function and communication needs. In almost all organizations with CSR programs, PR is used to communicate the CSR activities to the public. They both help an organization strengthen its relationship with the stakeholder, build reputation and mitigate risks (Reeves, 2016).

\section{Elements of Corporate Social Responsibility}

CSR consists of two distinct elements: the explicit and the implicit. Explicit CSR refers to corporate policies which assume and articulate responsibility for some societal interests. They normally consist of voluntary programs and strategies by corporations which combine social and business value and address issues perceived as being part of their social responsibility by the company. A recent example was the response of Walmart, FedEx, Home Depot and other US companies to provide disaster relief to the victims of hurricane Katrina in 2005. The point remains that explicit CSR rests on corporate discretion rather than reflecting either governmental authority or broader formal or informal institutions (Matten and Moon, 2008). According to Matten and Moon, "Implicit CSR" stands for corporations' role within the wider formal and informal institutions for society's interests and concerns. Nonetheless, Porter \& Kramer, 2006 noted that implicit CSR is not a deliberate action of a company rather it is a reflection of the company's environment.

\section{Theories of Corporate Social Responsibility}

Traditionally, a company exists primarily to make profits. Nowadays, there are many issues to be dealt with apart from money making. Ethical responsibilities arise as the struggle for money proceeds. There are three different theoretical approaches to the responsibilities of CSR.

a) Economic responsibility: This is businesses responsibility to make money. In the competitive economy if businesses do not make profit, they would perish. There is no business without profits and nor is business ethics.

b) Ethical responsibility: The main focus here is the provision of fair labor practices for its employees and those of its suppliers.

c) Legal responsibility: This is a responsibility to abide by the rules and regulations and its compliance to the laws.

d) Philanthropic responsibility: This is a corporate philanthropy is related to benevolence.

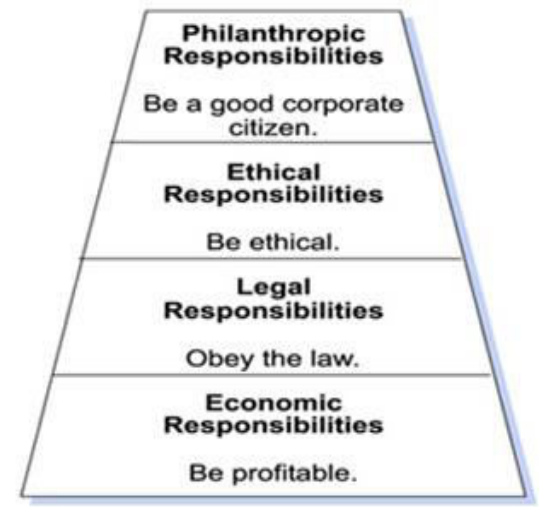

Fig 1: Carrol's CSR pyramid.

CSR shows that a company is about more than just its growth in profit rather it cares about its impact on the world and wants its customers to feel good about the 
products and services they buy. By making an effort to be socially responsible, they can ensure that their company leaves a lasting, positive impact on the community. Generally, the main features of Carroll's CSR Pyramid are that: CSR is built on the foundation of profit. Profit comes first in his ranking. Then comes compliance with all laws \& regulations. Before a business considers its philanthropic options, it also needs to be ethical.

\section{Visser Versus Carrol's CSR Pyramid}

From the point of view that humanistic motives have become complementary to the economic motives of CSR, Carroll's CSR pyramid has started to be criticized. Visser (2008) criticized Carroll's pyramid and the Western models of CSR in general for being based on research in an American context. It is however important to understand that Visser's model is a descriptive model of how CSR manifests itself in developing countries not how CSR should be practiced (Mathieson, 2011). The two scholars' perspective on the economic responsibility is also different even though they both placed it on the bottom of the pyramid. According to Visser (2008), economic responsibility is not about making profit but about the economic contributions from companies placing their investments on developing countries. However, Visser and Carrol (1991) both agree that profit is the basis for CSR practice. A clear answer to this question seems hard to find as the development in CSR has prompted a demand from consumers of more 'political correctness'. This is why it is few multinational companies that will declare profit alone as their main motive of CSR practicing. (Mathieson, 2011). According to Carrol (1991), legal responsibilities are society's expectations of company's compliance with laws and regulations Visser (2008) sates his objection to this definition saying that this has high focus in developed countries as companies could face consumer boycott and fines.

\section{The stakeholder's theory}

Stake holders are different individuals, groups that have interest in the operations of a business and affect or are affected by the decisions of the firm. The theory argues that even though shareholders are the prominent stakeholders of a business, the firm should create value not only for the shareholders but also for the stakeholders. The stake holder's theory was first described by Edward Freeman in 1984 in his book 'Strategic Management'. "The $21^{\text {st }}$ Century is one of "Managing for Stakeholders." The task of executives is to create as much value as possible for stakeholders without resorting to tradeoffs. Great companies endure because they manage to get stakeholder interests aligned in the same direction." (Freeman, 2010).

\section{Shareholders theory}

Contrary to Freeman's stakeholder's theory, Milton Friedman's (2002) shareholders theory argues that businesses do not have any obligation other than making profit and maximizing returns to their shareholders. Besides, if a government requires a business to seek something other than profit they are in the wrong. Friedman's stance in the idea of businesses selfishness and focus only in profit is from the point of view that if businesses are selfish, they do something that is beneficial to their employees, they don't produce defective products or harm their customers and it ends up benefiting them and increase their profit. Critics, however, raise their objection in that benefiting the public by doing something out of selfishness is not truly virtuous if it is not motivated by selflessness. Our action is praiseworthy if we do it only because it is good for others.

\section{The Triple Bottom Line}

John Elkington introduced the term "triple bottom line (TBL) in 1994. Due to the frustration with traditional oriented measures of business performance which emphasize profit as their key measurement, the triple bottom line approach came into existence (Ubagu and Gbuushi, 2020). Elkington's triple bottom line approach is the concept that encourages the assessment of business performance based on three important areas. Hence, profit, people and planet are aimed at measuring the financial, social and environmental performance of a business.

Profit (the traditional bottom line); is related with the effect of the company's activities on its share value and is done by calculating whether the company is making profits or a loss. 
People (the human capital bottom line) is about to what extent the company is socially responsible. It is concerned with the company's stake holders rather than shareholders which includes employees, suppliers and the wider public in which the business operates.

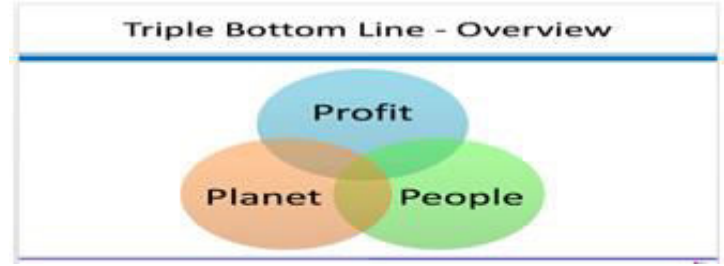

Fig 2: Elkington's Triple bottom line (TBL) of CSR.

Planet (the environment bottom line): measures the impact of the business activity on the environment. It is concerned with minimizing the company's impact on the environment by controlling energy consumptions, reducing waste and safe disposal of it.

Even though there has been the concept of the triple bottom line before, issues like the 2008 financial crisis BP oil spill cast an almost constant spotlight on corporate ethics and CSR practice. An investment in CSR can pay off though it requires much time and money. Studies found that companies that treated CSR seriously by setting concrete goals were the ones that profited from sustainable activities.

\section{CSR and Multinational Companies}

A number of scholars have emphasized the need for MNCs to be involved in CSR in the host countries. MNCs are more vulnerable to reputation loss, and in turn are more likely to be forced to engage in CSR initiatives because their reputation transcends national boundaries. Consumer expectations related to CSR have increased over the past five to ten years as the number of companies with social responsibility programs has grown. A typically one normally functions with headquarter that is based in one country while other facilities are based in locations in other countries (Trade, 2019). Research shows that MNCs use CSR to strategically manage the relationship with their stakeholders so as to gain legitimacy in the host countries. Due to the power and influence of MNCs in the host country's economy, it is expected that they participate in social responsibility to legitimize their presence. Denzin \& Lincoln (2011) stated that the validation is done through CSR and their motivation is not important if their CSR initiatives have positive impact on the environment and society. As it is unacceptable for MNCs to prosper in isolation from its stake holders, CSR is a very significant factor for MNCs to take into account. Stakeholders pressure MNCs to increase their CSR actions because they are attentive to ethical values of companies and sustainable growth. MNCs, indeed, claim to invest in becoming more environmentally sustainable.

\section{CSR in Developed Countries}

The concept of CSR originated from the developed countries and much of the literature and formal writings are evident in the United states and the concept of CSFR right from the beginning has been influenced by the context and culture of the developed the world. Consequently, many social issues, such as education, healthcare, or community investment have traditionally been at the core of CSR (Crane et al., 2008). The researchers investigated CSR in developing countries and realized that the contexts and institutional environments are influential in creating different results in those countries. Denzin \& Lincoln (2011) stated that we cannot look at CSR without considering the context and level of economic development of the country and operational environment of the organization. The finding showed that level of economic development defines the types of community needs which in turn shapes CSR implementation in an organizations.

\section{CSR in Developing Countries}

Subsidiary companies operating in another country have different stakeholders with various expectations based on the culture and context of the country and this makes standardizing their expectations difficult. Literature on the theory and practice of CSR in developing countries therefore remains scant (Belal, 2000). Global models of CSR should not replicated by developing countries without prior examination of country specific contexts. Five domains are recognized in the existing CSR models, namely economical, legal, ethical, philanthropic, and environmental. However most corporations in developing countries view philanthropy as their major social responsibility and largely ignore other domains (Crane et al., 2008). 
Developing countries face CSR challenges different from those faced by the (Crane et al., 2008) developed countries. Government in developing countries usually promotes FDI for economic development rather than promoting standard CSR practices among corporations.

\section{Drivers of CSR in developing countries}

CSR is perceived and practiced differently in developed and developing countries. Visser (2008) came up with ten drivers of CSR in developing countries to illustrate the difference. He stated that the drivers are not all unique for developing countries, but together they give a distinct perception of how CSR is conceived motivated and practiced in developing countries. Visser distinguishes between internal drivers, which refer to pressure from within the country and external drivers, which tend to come from the outside world (Visser, 2008).

\section{Corporate Social Responsibility in Ethiopia}

CSR in Nigeria is aimed at addressing the socioeconomic challenges of the country such as poverty mitigation, health care and education which is similar to the priorities of CSR in developed countries. However CSR approaches in developing countries are expected to respond to many social and environmental problems such as deforestation, unemployment, income inequality, and crime (De Oliveira, 2006). CSR is the least studied subject in terms of what it is expected to discharge in higher education (Elifneh, 2014). CSR in Ethiopia is not well developed and also the governance system takes the form of mere control in decision making instead of encouraging development and implementation of a well developed.

\section{Ethiopian Environmental Policy}

Environment is one of the main aspects the CSR plan can focus on when planning its strategy. In Ethiopia, land degradation is a serious environmental problem affecting productivity. The main causes of land degradation are nutrient depletion from agricultural lands, overgrazing and deforestation. Water and soil pollution by agrochemicals are becoming more dangerous in some areas. Besides, Pollution caused by industrial waste is also a seriously growing environmental problem in urban areas (The Federal Democratic Ethiopia Environmental Protection Authority, Dec 2011). This to ensure that essential ecological processes is sustained, biological diversity is preserved and natural resources are used in such a way their productive capabilities are maintained and the needs of future generations is not compromised (Basu et al., 2020).

\section{CSR in achieving Millennium Development Goals (MDGs)}

Millennium development goals and CSR have the same motives and goals relating to economic, social and environment. Hence, CSR needs to be harmonized with governments programs to achieve MDGs (Denzin \& Lincoln, 2011). It's not easy for governments only to achieve the MDGs without the support of the private sector and multinational companies should take their own part by doing CSR. The way of harmonizing the government MDGs and companies CSR in backing up the achievement of the goals has become the problem. Cahyandito has depicted the harmonization simply as follows.

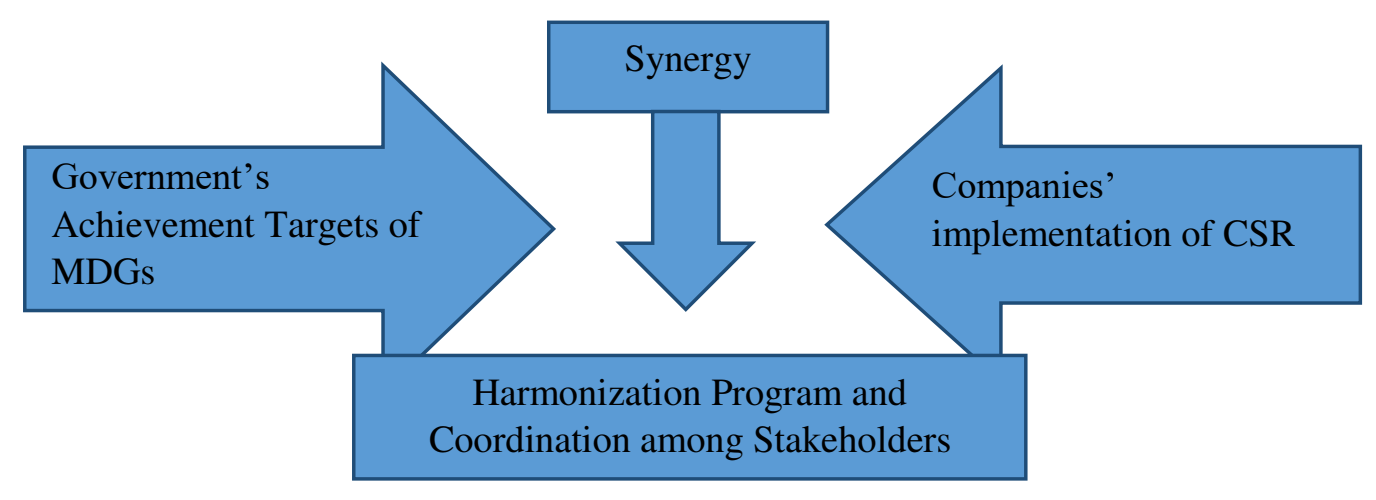

Fig 3: Haronization of MDGs- CSR. 
This harmonization process is initiated by governments MDGs short programs - example Ethiopias Growth and transfromation plans) and should be synergized with private sectors CSR programs. This requires other parties like ministries and regions and administartions at different levels aas wel as the private sector to mutually cooperate. Governments shoulsnot force compabies to do CSR and if they do it can be considered as double taxationGovernments are not involved in this process there is except in the process of quality assurance. This is to assure that the achievement of MDG work program is carried out in accordance with work plans prepared jointly by the Government and the company.

\section{MDGs and the private sector}

MDGs are important for the private sector to fulfill their responsibility as global citizens to resolve problems that may arise in the future and keep the market healthy for business and increase business opportunities (UNDP, 2003). Furthermore, the United Nations in its UN-private sector cooperation mentions the private sector's engagement in CSR at different levels can help achieve MDGs.

Table 1: UN-public private sector cooperation

\begin{tabular}{|l|l|}
\hline CSR activities & Forms of cooperation \\
\hline Participation in Global compact & Support of Global Compact projects in developing countries \\
\hline Awareness promotion \& publicity to achieve MDGs & $\begin{array}{l}\text { Gaining free publicity space from various mass media to } \\
\text { place advertisements and commercials as part of a "Poverty } \\
\text { Eradication Campaign }\end{array}$ \\
\hline $\begin{array}{l}\text { Engage in social contribution activities such as } \\
\text { volunteer work and contributions in kind in order to } \\
\text { achieve MDGs }\end{array}$ & $\begin{array}{l}\text { scholarships for children from low income families in } \\
\text { cooperation with UNDP to provide higher education, job } \\
\text { training, etc. }\end{array}$ \\
\hline $\begin{array}{l}\text { Support of existing projects of UN organizations by } \\
\text { contributing funds or other resources (such as } \\
\text { manpower, knowledge, expertise \& goods }\end{array}$ & $\begin{array}{l}\text { Private sectors joint efforts with UN to supply safe water, } \\
\text { education, etc }\end{array}$ \\
\hline $\begin{array}{l}\text { Products and services provided to the poor and } \\
\text { deprived at low prices }\end{array}$ & $\begin{array}{l}\text { Microfinance project in Kazakhstan to support development } \\
\text { of small businesses in cooperation with Citi group }\end{array}$ \\
\hline
\end{tabular}

Note: UN-public private sector cooperation from UNDP (2003)

\section{The UN Global Compact and CSR}

The Global Compact is a voluntary initiative supporting global framework for sustainable development through corporations as members of a society. The UN global impact established ten general principles for companies CSR activities that are founded on internationally recognized conventions related to human rights, environment and anticorruption. I have tried to relate company CSR activities to the following ten principles of Global Compact in short.

\section{ISO 26000:2010-Guidance on Social Responsibility}

International Organization for Standardization (ISO) is the world's largest developer of international standards. There is a key linkage between the UN Global Compact's ten principles and the ISO seven core subjects of social responsibility. ISO 26000 is recognized by the European Commission as being part of the "core set of internationally recognized principles and guidelines regarding CSR. Ethiopia has a national standard body called Ethiopian standards Agency established in 2010 aimed at making manufacturers and service providers to comply with internationally accepted standards. ISO 26000 doesn't specifically discuss CSR, rather, social responsibility in general as it is applicable to all kinds businesses. According to ISO 26000, a company should avoid contributing to any negative impact in its relationship.

\section{METHODOLOGY}

Research Design - The main objective of this study is to explore the CSR practices of a multinational companies in Ethiopia with specific reference to 
Heineken Brewery factory. In this research, the researcher used qualitative research method as the researcher is interested in describing the CSR practice of a multinational company in Ethiopia. The intent of qualitative research method is to describe a process or experience and to this end, the goal is to make meaning of experiences or phenomena by following data as they emerge. With the overall purpose of understanding a situation or how something is experienced in a deep and meaningful way, qualitative research methods are not a variation of an experiment, but are based on a very different philosophical perspective that gives credence to different ways of knowing (RF Cruz, 2016). There are goals for which qualitative research method is espceially useful one being the goal of understanding a particular context in which participants act and the influence this has on their actions .It is used to study a small number of individuals and situations (cases). This study is aimed at describing the CSR practice being studied and help improve the existing parctice of the CSR of the company.

Qualitative research involves an interpretive and naturalistic approach: "This means that qualitative researchers study things in their natural settings, attempting to make sense of, or to interpret, phenomena in terms of the meanings people bring to them". The design of the research is case study as it focuses only on a single company's CSR performance. Case study has its origins in qualitative approaches to research in the disciplines of anthropology, history, psychology, and sociology and it has become essential methodology in understanding complex issues. It is a versatile form of qualitative research most suitable for a comprehensive, holistic, and in-depth investigation of a complex issue. "a qualitative approach in which the investigator explores a bounded system (a case) or multiple bounded systems (cases) over time through detailed, in-depth data collection involving multiple sources of information (e.g., observations, interviews, audio visual material, and documents and reports) and reports a case description and case-based themes." Creswell (2009) that in case study a researcher explores in-depth a program, an event, activity, a process or a group. The researcher of this study believes that in this study case study method is

UniversePG I www.universepg.com employed to describe or explore the CSR activity (the case) of the Multinational brewery company (single company) in Ethiopia. Bearing this in mind, the researcher chose case study method to study the CSR case in terms of what the company does in the people and planet aspect of the triple bottom line.

\section{Methods of data collection}

As The Journal of Economic Development, Environment and People clearly put it, interview, observation and document analysis are the ideal methods for collecting qualitative data. It states the ways data can be collected for qualitative research as "qualitative research data are descriptive, in the form of interview notes, observation records, and documents; and data are analyzed inductively." As a result, the researcher collected data for this study using in depth interviews, observation and document analysis methods for triangulation helps to assure the validity of the thesis. Different sources of information were approached using various methods to make the finding valid. In depth interview is used when the data needed is not available in any other form and there is a need to talk to people, listen to their ideas to get the necessary data (Mason, 2002). The Sage Encyclopedia of Qualitative Research Methods further reiterated the use of interviews in qualitative research by saying that "qualitative researchers ask people directly about what they think, feel and do in order to get the data they want." The researcher of this study employed face to face interview by going to the site using semi structured open ended questions that helped produce opinions from participants. The researcher needed to gather in-depth information about the experience and perspectives from the participants for in-depth study of the topic in question because qualitative study is carried out to understand a phenomenon deeply and in detail. In addition, field observation is carried out to observe what is happening to the people and the environment. This helps to learn what is taken for granted in a certain situation or environment and to discover what is going on by watching and listening. Specifically in this study, what Heineken brewery company is doing to the society and the environment (people and planet) is being explored and observation is essential. Finally, documents such as reports, administrative documents are collected and analyzed. 


\section{Population and sampling technique}

The population for this study are the nearby kebele residents of Kilinto Heineken brewery plant and the CSR head of the company at the head office around Sarbet. Samples from the kebele will be selected based on availability whereas samples from the company will be taken purposively. Hence, head of the CSR section of the company will be interviewed. Besides, public relations head of the district where the brewery plant is located will be part of the sample selected purposively. Gentles et al., (2015) defined sampling in qualitative research as "the selection of specific data sources from which data are collected to address the objective of the study. Unlike quantitative research where sufficient large sample sizes are required, qualitative research requires smaller samples. The authors further discussed that the aim of sampling in qualitative research is to garner information that enables the researcher to understand the depth, complexity and context of a phenomenon rather than to represent the population. The most common criterion to determine whether sufficient sample size has been taken in qualitative research is saturation. Data saturation is when the researcher reaches a point of informational redundancy and further data collection brings little or no nothing new to the study. The researcher's goal is not to generalize from a sample to a population but to describe and interpret the phenomenon.

\section{Data Analysis techniques}

Qualitative data analysis is the classification and interpretation of linguistic or visual materials to make statements, to discover and describe issues and practices (Flick, 2013). The purpose is comparing different cases, materials or texts that help describe a phenomenon in detail. Qualitative content analysis method is used to analyze the data collected. Content analysis is a widely used qualitative research technique . Rather than being a single method, current applications of content analysis show three distinct approaches: conventional, directed, or summative. All three approaches are used to interpret meaning from the content of text data and, hence, adhere to the naturalistic paradigm (Hsiu-Fang Hsieh, 2005). Qualitative research is considered as a flexible method of analysing text data with attention to thecontent and contextual meaning of the text.As a result,the researchere uses this method to analyse the text data collected by interviews, observastion and documents. The researcher of this study applies cross sectional and categorical indexing of the raw text data and interpretative analysis will be given. Cross sectional data are data collected from different sources at the same point in time using different sources. Crosssectional indexing or categorical indexing includes "devising a consistent system for indexing the whole of a data set according to a set of common principles and measures" (Mason, 2002). Themes and theories are derived from the categories and then interpretations and descriptive analysis are provided in relation to the research questions and related literature.

\section{RESULT AND DISCUSSION}

This study aims at exploring the CSR practices of Heineken brewery in it Walia brewery plant located in Kilinto. In-depth interview was conducted with 11 participants from Akaki Kality Sub city wereda 9. The interview questions were semi structured and the interview carried out with the respondents was interactive with some follow up questions. Documents of CSR plan, reports and press releases from Heineken were collected from their website and analyzed. The researcher also made field observations based on a checklist points for observation. The researcher analyzed the data obtained by the previously mentioned three methods. An attempt to contact the External relations head of Heineken was unsuccessful but the researcher believed that the CSR initiatives and reports on their website could suffice to carry on the analysis.

\section{Heineken's CSR-The Environment}

Multinational companies' increasing social awareness has led to the development of a CSR policy whose implementation impacts on their overall marketing communication, both at their strategic and operational levels. However, a gap is felt in the integration of the policy and the operational levels. Companies have the duty to cover the environmental implications of their operations, products and eliminate waste and emissions, maximize the efficiency and productivity of its resources; and minimize practices that might 
adversely affect the enjoyment of the country's resources by future generations. CSR is no longer a luxury; it is a requirement to remain competitive in the business world. Heineken invested in Ethiopia buying Harar and Bedele breweries and later on establishing its own brewery plant in Kilinto to produce a new brand Walia. "Brewing a better world" is what Heineken is known for when it comes to sustainability throughout the world. The idea of sustainability as a business priority means that we act now to mitigate the impact of environmental and social risks and that we look at ways to create genuine economic opportunities for both our business and our stakeholders.

The company stated its areas of priority in sustainability as protecting water resources, reducing Co2 emissions, sourcing sustainably, advocating responsible consumption, growing with the community and promoting health and safety. Even though a company's CSR policy and strategy is required to be dependent on the context of social and environmental problems, and in this case should consider the social, environmental and workplace conditions in Ethiopia, Heineken's CSR strategy in Ethiopia seems similar to that of the global company's plan. Among Heinekens focus areas, sourcing sustainably seems the point they have worked and reported more than the others. Heineken partnered with Agricultural transformation Agency and devised a four year program named community revenue enhancement through technology extension in Ethiopia (CREATE).The company clearly stated the reason for investing a hefty amount of money on this. It is to reduce import of malt and at same time supporting the community. The project devised to support about 20,000 small holder farmers engaged in barley production. In fact, Multinational companies as their sound CSR initiative, should give preference to local areas and where the company operates.

A public private partnership was also signed with Harari regional state to provide Harar with sustainable Water resource. Heineken has also made a stride to make a positive impact on health care and planned to invest in improving the health care services of Bedele as soon as it bought Bedele and Harar breweries. It provided Bedele health center with an ambulance, healthcare facilities and training as it is indicated in the company's report. The big commendable step can be the inclusion of CSR as an integral part of its business. Many companies make their reports look attractive to auditing and regulatory bodies without taking action. It needs to be further proven by checking the environment and the society. CSR initiatives vary for each companies of the MNC operating in different countries with different social and environmental demands based on factors like size, culture and level of development. Manufacturing companies have numerous environmental challenges and are expected to integrate environment in to every part of their operation. The similar steps in every company's way of addressing environmental issues such as statements showing the respect for the environment in the production and distribution of their products is not country or sector specific and neither is it beyond compliance to the legal requirements to operate. This should, however, not be underestimated. They should show readiness to go beyond such generic statements. The researcher made field observation to the facility where the factory is located. Based on the researcher's observation, there was a terrible smell in the direction where the water waste goes to the Akaki River. The view was not good either. It flows in a waste water tunnel a little distance until it moves a bit far from the factory and then released on open surface to the river. No disturbing noise was heard though. There is a primary school adjacent to the brewery plant and one key informant on this issue said"

We are in trouble because of the bad smell of the company's waste water. They release it directly to the Akaki River nearby. It is so sad; Teachers left because of health concerns. Parents brought their children without knowing the bad smell that might impact the health of their children but withdrew their children from the school at mid semester and took them to other schools. Those who can't afford to pay school fee for their children in other schools are suffering and worried about their children's health. The school is meant for teaching children of the lower income families. 5-6 students left school for the reason that they couldn't stand the smell. 
Today, the weather is relatively good, you may not feel the intensity of the bad smell and our suffering (Interviewee 2)

Another respondent explained that they lodged a complaint against this case up until the Sub city level and the company responded it would fix the problem. Later on, the company said it introduced a state of the art waste water disposal machine. However, the residents do not see any improvement beyond the news. This year again the wereda made a move to ask the factory manager and the reply was not any different from the previous one. They said they tried their best to reduce the impact on the school community and the society at large. The wereda reiterates that the company once denied entry of reporters to give coverage of the factory. This is irresponsible business practice in way that they are not transparent about their business practice. This has offended both the wereda officials and the community concluding that it is not responsible for its practices. The respondent explained the procedures followed to combat the problem bore no fruit. Many respondents believe that the Kilinto branch of Heineken brewery is not exercising at least the minimum expectation of the society. A resident also raised similar concern and said that -

Walia has become known for its bad smell of what it disposes; we only remember it for its bad smell. Nothing more. Our brothers died here when it came to build its factory for they were not willing to leave their land. They were not compensated enough. It only brought inconvenience to us. We expected the coming of Heineken here would come with lots of job opportunities for us, the youth but it did not. (Interviewee 3)

The issue is not about how the waste should have been disposed rather communicating with the public about the benefits of the company's presence in the area to the residents and to the country. Heineken could have done something greater than mitigating the effect of the waste water and be remembered in association with other good action. This means the society is not happy about the way the company deals with their complaints. They think, Heineken doesn't care for the people but for its profit. The public's complaint is indeed substantiated by the statement in Heineken in that Heineken stated;

"after building our Kilinto Brewery, Phase I \& II, we became aware that community members and media don't have the full picture of our investments, process, and discharge related to Waste Water Treatment Plant After building our Kilinto Brewery, Phase I \& II, we became aware that community members and media don't have the full picture of our investments, process, and discharge related to Waste Water Treatment Plant. We put together with the relevant stakeholders to see with their own eyes our state of the art Waste Water Treatment Plant and more importantly, we had the Ethiopian Environmental Protection Agency present to verify that our process and effluent meet the legal standards of the Ethiopian EPA law. (Heineken brewery Ethiopia website.)

The report is of the company's compliance to the legal requirements instead of the solution to what the residents raise as a problem. If it the waste water was treated well as the company believes, it could have been better to convince the society, let them see for themselves if possible, and deliberate on what the waste water could have been used for. CSR can be seen as insincere by the community unless effective thorough community dialogue is held to engage with the public. This indicates their strategy lacks strategic communication with the society and are not communicating the public what they are doing and the company really cares for them and they are not neglected. Whether Heineken is doing CSR genuinely or not is up to the public's understanding of Heineken and depends highly on Heinekens communication with them.

Ethiopian Environmental Protection Authority made a visit to what they called the state of the art waste water treatment plant they introduced. Regarding compliance to the regulation of the country, this can indicate that Heineken follows the environmental rules and regulations of the country. Even after Heineken bought the waste water treatment plant, which they said is the first of its kind in Ethiopia, there was still a grievance. Some respondents believed that the smell has been reduced to a very little extent while there are 
people who complained that the brewery factory has a negative impact. It is still a concern whether Heineken are taking CSR action because of the need to act proactively, because of image, or imposed by the law. What can be concluded at the moment is at least they haven't made the public aware of what the company was doing no matter what its motives are. What the researcher observed in the vicinity of the factory was space for tree plantation around the pedestrian area which could have been utilized by the company's CSR. Tree planting is one of the CSR programs of a company to preserve the environment and promote environment sustainability. There is muddy road around the compound of the factory. It was rainy day when the researcher made a visit the second time. Some places were inaccessible due to the mud. The finding from the observation of the researcher and Heineken's CSR website shows that the company has not planned and carried out any climate change initiative in this specific site. Making the vicinity of the factory attractive and green would show the company also cares for the environment. Employee's engagement in tree planting campaigns and environment cleaning independently or in collaboration of the society is one of the ways of employee engagement in company's CSR especially where there are large numbers of workers like Heineken. From the point of view that Heineken has planned and carried out related activities in its two other factories in Bedele and Harar, there were no initiatives by Heineken to conserve energy and address environmental issues in Kilinto.

On the other hand, Heineken claims it was practicing CSR to protect the environment from its own side and The PR head of the Akaki sub city wereda 9 confirmed it. The company decided to fully sponsor and cover the total expense of the drainage construction of wereda 9 which was beyond wereda's capacity to combat the problem caused by the flooding in the area. The same respondent mentioned that Heineken cooperates with the wereda administration if the wereda requested any help. The problem with Heineken, according to the respondent, was they failed to solve the problem regarding the bad smell of the waste water. Heineken's support is always based on our request; it doesn't initiate. Residents' main

UniversePG I www.universepg.com complaint in relation to this issue is that "Heineken always has someone to please, it doesn't look at the real problem that needs to be solved. They act to please the officials they want." Their 2018 CSR report is available with emission, water use, and other focus areas covered. On Heinekens website, there is a separate report about their water use in Ethiopia. Practically, Heinekn exercised CSR in its two brewery plants, Bedele, and Harar, to increase water availability and sustainable use. There are no indications in its report so far about what has been done or what is planned to be done in its Kilinto Branch. Heineken stated that in Harar, we signed a Public Private Partnership with the Harar Regional State and other stakeholders, to ensure long term water availability in the area". Kilinto residents, however, said they have lost their water source which they blame it on Walia brewery plant. A respondent mentioned the negative impact of the company on their water supply and said,

"We had a meeting recently and teachers complained about the hygiene of our children but we can't help. It is difficult to get water. Walia took our water. There was a pipeline which is now diverted to the company. They should have cared for our children and the society as a whole. We got water from a different line with the help of plan international but still it is not enough" (Interviewee 7)

Heineken revealed its sustainability report in 2018 report and it indicates that water consumption decreased $32 \%$ and $\mathrm{CO}_{2}$ emission decreased $47 \%$ since 2008. $37 \%$ of raw materials used in Africa and Middle East were sourced from within the continent. This is a general report including the breweries in developed countries. The researcher believes a separate CSR report should have been carried out for Ethiopia so that it is possible to evaluate its CSR. An example could be one of its own reports on Bedele Brewery plant under the title "Bedele brewery-on track to reduce water consumption" which describes Heinekens responsibility to promote responsible use of water. It mentioned its reduction in water consumption from $10.9 \mathrm{Hl}$ in 2011 to 4.56 in 2016. Close to four years in operation, Heineken didn't reveal any water consumption report or plan for its Walia plant. CSR should be strategically carried out and has to be different in different contexts and countries. Scholars 
like Visser (2008) raised the reason for such flaws in CSR report in developed countries emanates from weak legal bodies in developing countries. Though Environmental Protection Authority requires companies to do so, the implantation is not strong enough.

\section{Heineken's CSR - The Society}

Community engagement is key to company CSR practice as it enables them get contextualized understanding of expectation of the community. PR professionals should take part in facilitating the dialogue and communicate CSR campaigns. Professional communicators give life to CSR. Companies should listen to expectations of the society, and collect opinions of the business operations so that solutions could be given to problems in the society. Heineken doesn't seem to understand that its business depends on the trust and credibility by the public. The disturbing smell is a concern for the health of the residents. An interviewee explained 'We use air freshener every day to get rid of the bad smell when we get to our office. it is really terrible". Little has been done regarding safeguarding the wellbeing of the society in a long term. Walia has been operating there close to four years now but the project to support Kilinto Health Center has not yet started. There is, however, according to Heinekens report, a plan to renovate, equip and furnish the health center and run community awareness programs. This is where lack of implementation of the beautiful CSR plans comes in point. When a respondent expressed his dissatisfaction about what Heineken did to Kilinto health center, he said -

"Just one Ambulance; it is a joke. This is so little when we see it in relation to this giant profitable company. It has to do more than this to the society. We are getting sick and this needs solution. This company is selfish. St George is taking part in different social responsibilities better than Walia. It is saddening that Walia uses our precious endemic animal's name and it did nothing to save the animal when there was wild fire in the Semien mountains national park"(interviewee 11)

This shows that Heinekn lacks the harmonious relationship and effective PR strategies to create the bond by communicating their CSR professionally. UniversePG I www.universepg.com
One ambulance could have earned Heineken much respect had they built the relationship with the community through dialogue. Heineken Africa foundation invested in Bedele for hospital expansion and buying other materials. In Kilinto, no such investments were made by the initiation of the company other than what is in the pipeline. However, based on the request of the wereda administration, it has practiced lots of CSR activities including building offices as expansion in the wereda 9 of Akakii Kality sub city. As part of its job creation and supporting small businesses in the community, Heineken built 8 shower rooms for the youth to rent and get income out it. The wereda report indicated that the company invested close to 8 million birr. Education faces many challenges related to quality education and budget constraints. This gives rise to opportunities for businesses to take part in CSR in education sector. Businesses participate in education for different reasons including positive companies get involved in education for a number of reasons including positive image. In this case, Kilinto primary school's location closest to the factory made the public expect more and Heinekens negligence was seen clearly. According a respondent from the school community, the school submitted the proposal requesting help to build them a fence for the school compound, and looking for other financial and technical support. He said -

We along with the parent representatives of the school wrote a proposal in 2018 seeking support from Walia for the school fence, football field and other material supports but it declined. it is so hard to approach them. The security is tight that no one can talk to an official in the factory. Though we finally managed to talk to them they were not willing to provide us any help. They gave teachers 3 cases of beer for recreation a bit farther from their school. We consider this advertising, not genuine. We repeatedly asked for help from Heineken but it is not willing and now we lost hope and stopped. They should have collected opinions from the public and identify the needs and expectations of the society. What are they going to support if not education?'(Interviewee 9)

When one thinks about CSR, beyond mitigating the negative impact a company can have on the 
environment and the society, financial or technical support to schools and health centers is at the forefront. No respondents had a different view regarding their contribution to health and education. Some even went on to laugh at what Heineken did in donating one Ambulance to the health center in the wereda. According to one Key informant interview, in sports and small businesses for the youth, Heineken did well both in terms of sustainability and problem solving. It signed an agreement to build covering the construction expense of new designed stadium whose design is done by a foreign company. It also donated 8 containers for the community cooperatives for use as shops to sell their goods at a relatively lower price which both benefits the cooperatives and the beneficiary customers. In addition, it helped build offices for the wereda 9 administrations. Heineken in its report also revealed that it was working with the community in Kilinto. The report reads "In order to strengthen our local connection in Kilinto, we supported 12 Idirs nearby to our Kilinto Brewery. This was done through the purchase of tents, chairs, cooking utensils, and loud speakers with its accessories which costs over 750,000 birr". An interviewee replied in an interview undermining Heineken's donation and said -

This is something we could have done, we can afford to buy our Idir materials. We need more from Heineken, but itis not helping us with what we can't afford like water and supporting the school and creating job opportunities to the youth of the community. It promised to do more when it first came here but we are not seeing it now (Interviewee 4)

Responses indicate that the community asked in an organized way about their low compensation given to them to construct the brewery plant and seeking job opportunities in the factory. The company replied it could not give priority in employment as it has to follow its own law of employment and employees are brought via agencies. Heineken doesn't have to necessary go against its laws to employ the residents but create job opportunities outside its business and support the youth like what it tried to do by providing them containers and shower rooms. The characteristics

UniversePG I www.universepg.com of their CSR is somewhat reactive aimed at changing the negative image by the community. The increasing pressure from the youth in the community demanding job opportunities and soaring complaint about the waste water trusted the Company to build few shower rooms that create some youth a job and the Idir community buying them tents. Working on sustainable development of the society needs way more than helping them meet their tentative needs. Heineken sees CSR initiatives as more of a strategy in the pursuit of having a good image of the company instead of moral obligation to give back to the society. The company's doing its CSR thinking that it is doing well while the society's demands are very different which usually happens when they companies practice CSR without studying the needs and problems of the society and the country in general. Such CSR practices of firms will not promote public interest. Stakeholders should discuss on what should be done in addition to the company goals and strategies of CSR. Heineken adopted its own CSR with its key focus areas clearly put. What is required is to look into the community, localize their strategy and check if is possible to implement it in the society to help promote their wellbeing. Sometimes, MNCs CSR plans might go against the local people on which it is implemented. Heinekens CSR priority areas are not realistically on the ground and felt by the public in Kilinto. Continuous discussion with the community should be carried out to deal with their concerns and accordingly devise their CSR. Commenting on the engagement of Heineken in supporting the society through donation, a respondent explained -

"What I remember is, this year, the company bought 45 sheep and 45 Cases of beer and supported the less fortunate and elderlies for their Holiday celebration. Besides, it donated two million birr to build 8 shower rooms for the youth to do business with it. It handed over tents and other materials for Idir. That is it. "(Interviewee 10)

The aforementioned statement shows that Heineken exercises CSR practices in the society that go in line with eradicating extreme hunger and poverty and reducing child and maternal mortality. However, this is occasional and it is not practiced sustainably to bring about lasting solution to the families in need. 
What Heineken did for the youth as job creation and to Idir members is commendable though a planned continuous activities of this kind should be carried out. Heineken also sponsored to fully cover the total expense of the drainage construction of wereda 9 which was beyond wereda's capacity to combat the problem caused by the flooding in the area. This CSR practice is beneficial to both the environment and the society. Safety of products and their impact on society's health is part of the responsibility of the business as a social actor. The necessary requirements for product and service information and labelling was available on the bottle and no safety related issues have been raised so far. The company has been advocating responsible consumption on various platforms the beginning of which is their labelling on Walia as "Be agbab, Belik, Behalafinet".

\section{Heineken's CSR in relation to the triple bottom line}

Elkington's triple bottom line argues for businesses to measure their CSR success based on three perspectives namely people, planet and profits. Organizations performance in each category represents their commitment to their stakeholders, the natural environment and their economic profits. Environmental management strategies are adopted as company's CSR activities for growing a company's image and cumulative effects on their environment as well as their profits. The researcher tried to look into the two of the triple bottom line i.e. people and planet categories. The response by some of the respondents shows that the residents are concerned about their health and well-being as they are affected by their inconvenience in the surrounding physical environment. They demanded for corporations to be held accountable for their impact on this environment. Sustainable community development activities such as promotion of education, promoting gender equality and empowering women are left almost uncovered in the company's CSR practice in Kilinto. Another respondent commenting on this added that

There was no single support given to the school and the children locate closer than any institution which the company can see it before anything else. Despite the effort made by the school community in collaboration with the parent representatives,
Heineken couldn't give any donation. Whom else can it provide support to if it is not for the children and education? It should have considered it before we requested. (Interviewee 8)

Heineken has been engaged in both the environment and the community though it didn't prevent the people from expressing their dissatisfaction. Heineken didn't have any involvement specifically in the education sector which came in to attention as failure to take part in CSR. The donation to the people in need and the health center as well as the Idir community are the positive CSR engagement of the company in the society. Relatively, Heinekens CSR engagement in the society is better than what it did to the environment. CSR in environment can be done in many ways that are invisible to the respondents in the interview conducted like reduction of $\mathrm{CO}_{2}$ emission. But, problems related to water resource consumption, pollution and tree planting could have been solved and recognized by the society. CSR initiatives on environment are very crucial in earning the company a competitive advantage. Environmental CSR initiatives like climate change, water use and energy consumption play a major role in corporations in today's business and Heineken is no different. Resource management and energy consumption are key aspects when talking about environmental CSR of corporations like Heineken as a brewery company. Separate report for its Ethiopian Kilinto brewery plant were not done and this can mean both lack of transparency and lack of effective environmental CSR. Heineken doesn't recognize the importance of transparency to earn trust of the society CSR information is not communicated to the stakeholders. The Kilinto society does not believe that Heineken cares for their wellbeing and underestimate for what Heineken does as CSR such as donation. Community service was not provided by the company. Responsibility to the society as a social actor and creating smooth relationship with the society is weak. The purpose of the engagement of the public in CSR is to align the business activities of the company to achieve societal goals. Heineken has well defined CSR goals but it lacks integration of the strategic and operational levels of the responsibilities. Heineken is doing little in its people and planet bottom-line when it comes to a 
responsibility to promote the wellbeing of the society taking in to account future economic, social and environmental justice. Environment, health, education topics were not well covered by Heineken. Local community engagement in discussing their expectation of the company and its CSR focus was weak in that the respondents indicated they were not considered in the operation of the business.

\section{CONCLUSION AND RECOMMENDATIONS}

The study explored CSR activities of a Multinational company Heineken in terms of the two elements of Triple bottom line- people and planet. From the interviews conducted, the observation made, documents and reports available on the website, the researcher came up with the following conclusion. The first research objective is related to exploring Heineken's CSR activities on the environment. Heineken has successfully incorporated CSR in to its corporate business strategy. While embedding it in its strategy is given due recognition as a good beginning, it lacks further clarity on feasibility and validity in Ethiopian context, especially in sub urban areas like Kilinto. Very little progress is made to conserve the environment in Kilinto. The company carried out much of its CSR in cooperation with the wereda administration as one institutional stakeholder based on request. Heineken's donation to Idir was made after mounting pressure from the residents. Heineken's contribution to the society is responsive instead of investing on sustainable social development issues. Heineken's lack of investment on CSR in the education and insignificant contribution to health sectors indicates the social contribution is very low. Finally, Heineken's performance in terms of the people and planet perspectives of Elkington's bottom lines is not strong enough. It doesn't have separately outlined policy regarding mitigating environmental and social impact of the brewery plant in Kilinto. Heineken CSR needs strategic vision in the context of and relevance to the stake holders in their different brewery sites with completely different stakeholders.

Based on the findings, the researcher forwards the following recommendations.

- Heineken should strengthen stakeholder engagement so that awareness among the general public about CSR should increase and UniversePG I www.universepg.com the implementation of CSR initiatives becomes effective;

- It should tailor its CSR initiatives to the needs of the society and the environment they operate in with a vision to bring sustainable solutions to the existing environmental and social problems with the next generation in mind;

- The company has to exercise CSR through employee's engagement in giving their time in addressing environmental and social challenges such as tree plantation, environment cleaning and participation in the community activities;

- Heineken should increase its commitment in supporting schools and health institutions since the challenges in developing countries are enormous;

- Heineken needs to make its CSR vision strategic and dependent in the environmental context and community needs where the plant is located;

- The company should be transparent about its CSR goals and communicate the company CSR to its customers;

- Heineken needs to balance its CSR oriented strategies distributing its contribution to the people and planet based on sustainability and care for the varied needs of the society;

- The company has to engage itself in public private partnerships to promote CSR by contributing to infrastructure, education, health and safe drinking water to the wider public;

- The company needs to devise a business strategy and CSR action plan in alignment with the social and environmental demands of the community for efficient performance;

- The company has to restructure its Public Relations department with PR professionals having the necessary strategic communication skills to strengthen and create harmonious stakeholder relationship through effective communication of CSR programs, relationship building and community relations.

\section{ACKNOWLEDGEMENT:}

I would like to express my special gratitude to my advisor Yohannes Shiferaw $(\mathrm{PhD})$ for his unreserved, relentless effort he exerted to help me make this study 
possible. Besides, I would like to thank the academic staff of Addis Ababa University, School of Journalism and Communication who provided me with academic and moral support throughout conducting of this thesis. Advice given by the Akaki Kality communication office was of great help in data collection for the study; thus, I am very much grateful. Finally, I would like to express my great appreciation to my friends and classmates whose constructive comments helped me throughout the study.

\section{CONFLICT OF INTERESTS:}

The author declares that there is no conflict of interest in the preparation of the paper.

\section{REFERENCES:}

1. Basu S, Roy A, and Karmokar S. (2020). Effectiveness of microfinance on household income generation strategy in the southwest region of Bangladesh, Asian J. Soc. Sci. Leg. Stud., 2(3), 56-62.

https://doi.org/10.34104/ajssls.020.056062

2. Belal, A.T. (2001). A study of corporate social disclosures in Bangladesh. Management Auditing Journal, 16(5), 274-289. https://doi.org/10.1108/02686900110392922

3. Carroll, A. B. (1991). The pyramid of corporate social responsibility: Toward the moral management of organizational stakeholders. Business Horizons, 34(4), 39-48. https://doi.org/10.1016/0007-6813(91)90005-G

4. Chan, L. Y. (2014). Corporate Social Responsibility of Multinational corporations. Tacoma: university of Washington. 1-28.

5. Clark, C. E. (2000). Differences between Public Relations and Corporate Social Responsibility: An Analysis. Public Relations Review, 26(3): 363-380.

6. Crane et al. (2008). The Oxford Handbook of Corporate Social Responsibility. Oxford: Oxford University press (pp.19-46.). New York: Oxford University Press.

7. Creswell, J. W. (2013). Qualitative inquiry and research design: Choosing among five approaches $\left(3^{\text {rd }}\right.$ Ed.). Thousand Oaks, CA: Sage.

8. De Oliveira, J. A. (2006). Corporate citizenship in Latin America: New challenges for business. J. of Corporate Citizenship, 21, 17-20.

https://doi.org/10.1093/oxfordhb/978019921159 $\underline{3.003 .0021}$

9. Denzin, N. K., \& Lincoln, Y. S. (2011). The SAGE Handbook of Qualitative Research $\left(5^{\text {th }}\right.$ Ed). Thousand Oaks, CA: SAGE Publication.

10. Elifneh, Y. W. (2014). The Corporate Social Responsibility Practices and Concerns of Addis Ababa University: Implications for Higher Learning Institutions in Ethiopia, Ethiopian j. of business and economics, 4(2): 310-335. https://doi.org/10.4314/ejbe.v4i2.5

11. Flick, U. (2013).The SAGE Handbook of Qualitative Data Analysis. London: SAGE.

12. Freeman, R. E. (2001). A stakeholder theory of the modern corporation. Perspectives in Business Ethics Side, 3: 144.

https://philpapers.org/rec/FREAST-4

13. Friedman, A. L., \& Miles, S. (2002). Developing stakeholder theory. Journal of management studies, 39(1), 1-21.

14. Gentles, S. J., Charles, C., Ploeg, J., \& Mc Kibbon, K. (2015). Sampling in Qualitative Research: Insights from an Overview of the Methods Literature. The Qualitative Report, 20(11), 1772-1789.

https://nsuworks.nova.edu/tqr/vol20/iss11/5/

15. Han, H., Hsu, L. T. J., \& Lee, J. S. (2009). Empirical investigation of the roles of attitudes toward green behaviors, overall image, gender, and age in hotel customers' eco-friendly decision making process. Intern. J. of Hospitality Management, 28(4), 519-528. https://doi.org/10.1016/j.ijhm.2009.02.004

16. Hopkins, Michael, (2004). "Corporate social responsibility: an issues paper" Policy Integration Department, Working Paper No. 27 World Commission on the Social Dimension of Globalization International Labor Office Geneva,

17. Hsiu-Fang Hsieh, S. E. (2005, December). Three Approaches to Qualitative Content Analysis. Qualitative Health Research.

18. Koswara, A. (2005). Communicating CSR practices: A website analysis of Indonesia's State owned entities. Australian Journal of 
Sustainable business and society. 1(1): 27-36. https://www.researchgate.net/publication/28686 $\underline{5462}$

19. Mason, J. (2002). 'Qualitative Interviews: Asking, Listening and Interpreting' in T. May (ed.) Qualitative Research in Action, London: SAGE.

20. Mathieson, T. L. (2011). The difference in CSR a "comparative" analysis" with "focus" on "cultural" differences "in" CSR" practicing "in developing and developed countries. Copenhagen: Copenhagen Business School.

21. Matten D. A. and Moon J. (2008). 'Implicit' and 'explicit' CSR: a conceptual framework for understanding of corporate social responsibility. Academy of Management Review. 33(2): 404-424.

https://doi.org/10.2307/20159405

22. Miller, Justin I. and Guthrie, Doug, (2007). “ The Rise of Corporate Social Responsibility: An Institutional Response to Labor, Legal, and Shareholder Environments", Institutional Determinants of CSR, Stern School of Business, New York University,

23. Reeves, H. (2016). Defining Public Relations' Role in Corporate Social Responsibility Programs. PR Journal, 10(2): 1-19.

24. RF Cruz, J. T. (2016). Reading and Understanding qualitative research. American J. of Dance Therapy, 39(1), 79-92.

25. Rupp et al. (2006). "Employee Reactions to Corporate social Responsibility: an Organizational Justice Framework", J. of Organizational Behavior, 27, pp. 537-543.

www.interscience.wiley.com

26. Shahjalal M. (2020). Can 'control-order' be implanted into the counter-terrorism policy of Bangladesh? A critical assessment, Asian J. Soc. Sci. Leg. Stud., 2(3), 63-70. https://doi.org/10.34104/ajssls.020.063070
27. Sharma, S., \& Mehta, S. (2012). Where Do We Go From Here? Viewing Corporate Social Responsibility through a Sustainability Lens. J. Of Contemporary Management Research, 6(2), 69-76. http://hermanaguinis.com/JOMCSR.pdf

28. The Federal Democratic Republic of Ethiopia Environmental Protection Authority. (DEC 2011). GEF Portfolio Identification Document. Addis Ababa.

29. Trade, D. O. (2019, March 21). Retrieved from https://www.globalnegotiator.com/internat ional-trade/dictionary/multinational-corporation -mncl

30. Ubagu MM, and Gbuushi JA. (2020). Perceived effect of motivation on the job performance of library personnel of universities in Benue state, Nigeria, Br. J. Arts Humanit., 2(1), 14-23. https://doi.org/10.34104/bjah.020014023

31. UNDP, (2003). Corporate Social Responsibility (CSR Corporate Social Responsibility and Millennium Development Goals.

32. Visser W. (2008). Corporate social responsibility in developing countries. The Oxford handbook of corporate social responsibility, 473-479.

https://doi.org/10.1093/oxfordhb/978019921159 3.003.0021

33. Wilcox, T. and Glen Cameron, (2006). Public Relations: Strategies and Tactics. Pearson and A \& B, 2006

34. $\mathrm{Zu}$, Liangrong, and Song, Lina (2008). "Determinants of Managerial Values on Corporate Social Responsibility: Evidence from China”, IZA Working Paper No. 3449, April 2008, 1-27.

http://dx.doi.org/10.1111/j.0042-7092.2007.\%2 000700.x

Citation: Gereziher B. and Shiferaw Y. (2020). Corporate social responsibility practice of multinational companies in Ethiopia: a case study of Heineken Brewery S.C, Br. J. Arts Humanit., 2(2), 36-55. https://doi.org/10.34104/bjah.020036055 (9) क 